\title{
Influence of Recycling Different Leachate Volumes on Refuse Anaerobic Degradation
}

\author{
Ma. C. Hernández-Berriel ${ }^{1,2}$, C. Mañón-Salas ${ }^{3}$, J.M. Sánchez-Yáñez ${ }^{1}$, J. Lugo-de la Fuente ${ }^{4}$ and \\ L. Márquez-Benavides ${ }^{*}, 1$
}

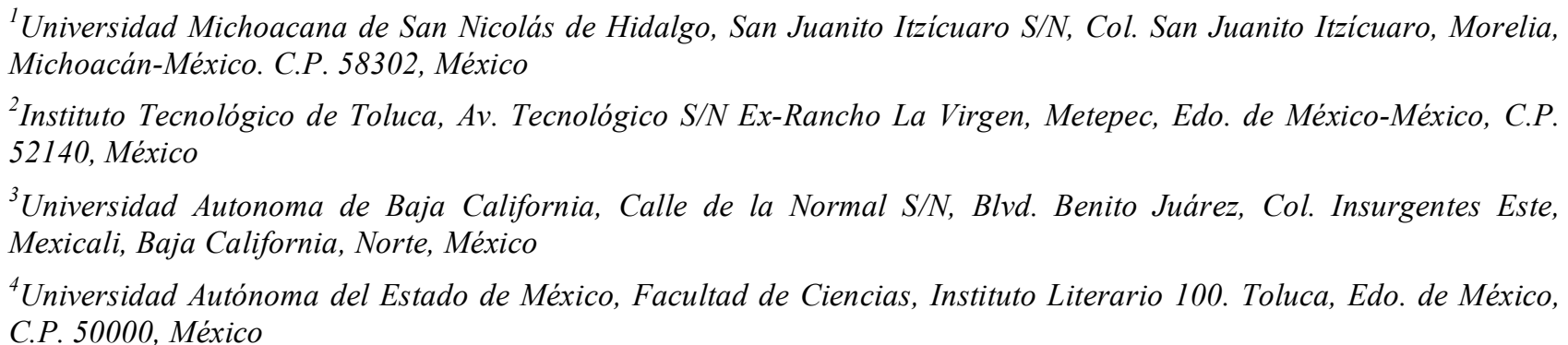

\begin{abstract}
The aim of this work was to determine the appropriate moisture regime, attained by leachate recycling, to achieve the highest municipal solid waste (MSW) biodegradation rate. To this end, leachate characteristics, methane production rate and changes in degraded refuse were studied. Twenty laboratory-scale bioreactors were loaded with MSW from the landfill of Pátzcuaro (Mexico), four were used as controls and sixteen were operated under leachate recycling to achieve moisture content regimes (\%MC) of 50, 60, 70 and 80\%, bioreactors operated for 264 days. Hydrolysis, acidogenic and methanogenic phases were determined and studied. ANOVA and Tukey's HDS tests revealed significant differences in leachate concentration characteristics when using different recycling volumes. Maximum methane production rate was found in the $70 \% \mathrm{MC}$ regime, whereas the highest volume was found to produce a wash out effect in the refuse matrix. Also, the highest total volatile solids removal was found in the solid phase of the $70 \% \mathrm{MC}$ regime.
\end{abstract}

Keywords: Municipal solid waste, leachate, moisture content, methane.

\section{INTRODUCTION}

According to data from the World Bank, Mexico accounted for a $2 \%$ of global greenhouse effect gases in the year 2002, of which landfills and final disposal sites of municipal solid wastes (MSW) contributed a $5.44 \%$ [1]. The utilization of biogas produced by the biodegradation of MSW is common in several parts of the world [2-5]; however, more information is needed in Mexico in order to persuade the authorities of the sustainability of this use, making the traditional landfill to evolve towards a landfill bioreactor.

A traditional landfill is a facility engineered for the final disposal of MSW that is designed and operated to minimize the negative impacts on the environment and on public health [6], but needing 20 or more years for stabilization [7, 8]. Given these long-term post-closure periods, barriers originally installed in the landfill are prone to exceed their useful life, thus opening the possibility for the infiltration to the soil of leachate and for the emission to the atmosphere of biogas, impacting on the environment and on public health $[4,9]$. The Solid Wastes Association of North America

*Address correspondence to this author at the Universidad Michoacana de San Nicolás de Hidalgo, San Juanito Itzícuaro S/N, Col. San Juanito Itzícuaro, Morelia, Michoacán-México. C.P. 58302, México; Tel: 52(443) 3340475, Ext. 116; E-mail: lmarquez@umich.mx
(SWANA) defines the landfill bioreactor as "any permitted Subtitle D landfill or landfill cell where liquid or air is injected in a controlled fashion into the waste mass in order to accelerate or enhance biostabilization of the waste" $[9$, 10]. Among the most relevant factors having an effect on biostabilization of MSW are moisture content and nutrients distribution, because these control a landfill bioreactor and optimizes the degradation processes mainly by the addition of leachates or other liquid amendments [4]. The advantages of leachate recirculation in a landfill include: (1) the settlement of the cell before the final cover is placed, thus decreasing possible damages to it; (2) increase of the effective density of MSW, and thus, of the landfill capacity; (3) the in situ treatment of generated leachates; (4) the increase of methane production rates; and (5) the acceleration of biodegradation of MSW, which may shorten the post-closure monitoring and reduce the global costs of the landfill [11-13].

The advantages of the landfill bioreactor over the conventional landfill have been studied for at least two decades $[14,15]$. Evidence exists of the benefits of leachate recirculation in the management of final disposal sites; however, applying the available information in Latin America is difficult because this information is mostly generated in industrialized countries where the generation and management of wastes do not correspond to that in the region. Furthermore, leachate recirculation must be made 
cautiously given that a disequilibrium between acidogenesis and methanogenesis or between saturation and stagnation may occur, which would negatively affect biodegradation and hence methane generation. Thus, the aim of this work was to determine the appropriate moisture regime by leachate recycling to achieve the greatest MSW biodegradation. To this end, leachate characteristics, changes in degraded refuse and methane production rate were studied.

\section{MATERIALS AND METHODOLOGY}

\subsection{Municipal Solid Waste Sample Preparation}

$50 \mathrm{~kg}$ of MSW were sampled from the working cell of the Pátzcuaro, Michoacan (Mexico) landfill, and $20 \mathrm{~kg}$ of soil from the intermediate cover. Once in the laboratory, MSW was characterized and subdivided in 15 groups of similar characteristics (Table 1). Products such as paper and cardboard were hand shredded to a particle size up to $1 \mathrm{~cm}$, glass and construction and demolition waste were crushed in a mortar to a particle size $\leq 0.5 \mathrm{~cm}$, and food and yard trimmings were grinded in a blade mill to a particle size $\leq$ $0.1 \mathrm{~cm}$. Each product was stored independently at $4{ }^{\circ} \mathrm{C}$ until utilization (no more than two weeks).

Table 1. Municipal Solid Waste Composition from Pátzcuaro, Michoacan, Mexico

\begin{tabular}{|c|c|c|}
\hline \multirow{2}{*}{ Component } & \multicolumn{2}{|c|}{ Composition } \\
\hline & $\%$ & $\mathbf{g}$ \\
\hline Food waste & 34.25 & 73.71 \\
\hline Yard trimmings & 31.86 & 68.56 \\
\hline Paper & 5.97 & 12.84 \\
\hline Plastic film & 4.74 & 10.20 \\
\hline High density polyethylene & 3.81 & 8.21 \\
\hline Glass & 3.48 & 7.49 \\
\hline Rags & 3.31 & 7.12 \\
\hline PET & 2.67 & 5.75 \\
\hline Construction and demolition waste & 1.91 & 4.10 \\
\hline Disposable diapers & 1.89 & 4.06 \\
\hline Metal & 1.76 & 3.78 \\
\hline Aluminum & 1.31 & 2.83 \\
\hline Waxed cardboard & 1.21 & 2.60 \\
\hline Cardboard & 1.07 & 2.30 \\
\hline Unicell & 0.76 & 1.64 \\
\hline Total & 100.00 & 215.19 \\
\hline
\end{tabular}

\subsection{Bioreactors Set Up and Operation}

\subsubsection{Laboratory Scale Bioreactors}

A mixture of MSW was prepared using the proportions shown in Table 1; the mixture was replicated to fill twenty (PVC) 412.24 mL-capacity laboratory-scale bioreactors (LSBs). A final cover (FC) of landfill soil (32.15g) was placed on top of the refuse, after which LSBs were hermetically closed. Each LSB was packed at a density of $600 \mathrm{~kg} / \mathrm{m}^{3}$, similar to that in the Pátzcuaro landfill.

The experiment was considered as a homogeneous random process having as a control factor the percent moisture regimen (\%MC), which was adjusted at 50, 60, 70 and $80 \%$. Bioreactors were set up using four replicates for each \%MC and were operated for 264 days at room temperature $\left(22 \pm 1.0^{\circ} \mathrm{C}\right)$.

\subsubsection{Operational Conditions}

Of the 20 LSBs, 4 were operated as controls and 16 were operated under twice per week leachate recirculation in order to reach the above-mentioned \%MC regimes. Fig. (1) shows a schematic representation of a LSB fitted to a leachate recirculation system and to a biogas displacement monitoring system. The initial humidification was made adding the corresponding volume of water (Table 2) to loaded LSBs, after which produced leachate in each LSB was placed in separate glass containers previously filled with 10 times the volume of the LSB. The resulting leachates were mixed in the leachate reservoir (Fig. 1e) and a volume corresponding to the desired $\% \mathrm{MC}$ was recirculated by means of a peristaltic pump (Fig. 1d). The volume of water and leachate to be recirculated in each LSB was calculated based on the moisture content of the MSW using Equation 1. The volume to be added (W) was determined by trial and error until the desired $\% \mathrm{MC}$ was reached.

$\% \mathrm{MC}=((\mathrm{WR}-\mathrm{DR}+\mathrm{W}) 100) /(\mathrm{WR}+\mathrm{W})$

where:

$\% \mathrm{MC}$ : percent moisture content of the refuse to maintain (in wet base)

WR: weight of initial wet refuse $(\mathrm{g})$

DR: weight of initial dry refuse $(\mathrm{g})$

$\mathrm{W}$ : weight of water or leachate to add $(\mathrm{g})$

Table 2 shows the experimental design adopted in which the volumes of water initially added were similar to the volumes of leachates to be recirculated in order to reach the desired \%MC (50, 60, 70 and 80\%). Obtained results were statistically analyzed using ANOVA and Tukey's Honestly Significant Differences (HDS) tests $(95 \%$ level of significance) by means of Statgraphics Plus $5.0 \AA$.

\subsection{Analytical Methods}

\subsubsection{Initial Refuse Analyses}

The MSW mixture was analyzed for $\mathrm{pH}$, moisture content $(\% \mathrm{MC})$, carbon content $(\mathrm{C})$ and nitrogen content $(\mathrm{N})$ using Mexican standards [16], and total volatile solids (TVS) using the 2540G method of APHA, AWWA and WEF [17].

Soil used as $\mathrm{FC}$ was also analyzed for $\mathrm{pH}, \% \mathrm{MC}, \mathrm{C}$ and $\mathrm{N}$ using Mexican standards [16], TVS were determined using the $2540 \mathrm{G}$ method of APHA, AWWA and WEF [17] and texture, by the Bouyoucos method [18].

\subsubsection{Leachate Analyses}

Leachate operational parameters were analyzed weekly: $\mathrm{pH}$, electric conductivity (EC), total solids (TS) and TVS using Mexican standards [16], chemical oxygen demand (COD) using the dichromate Hach method [19] (approved by 


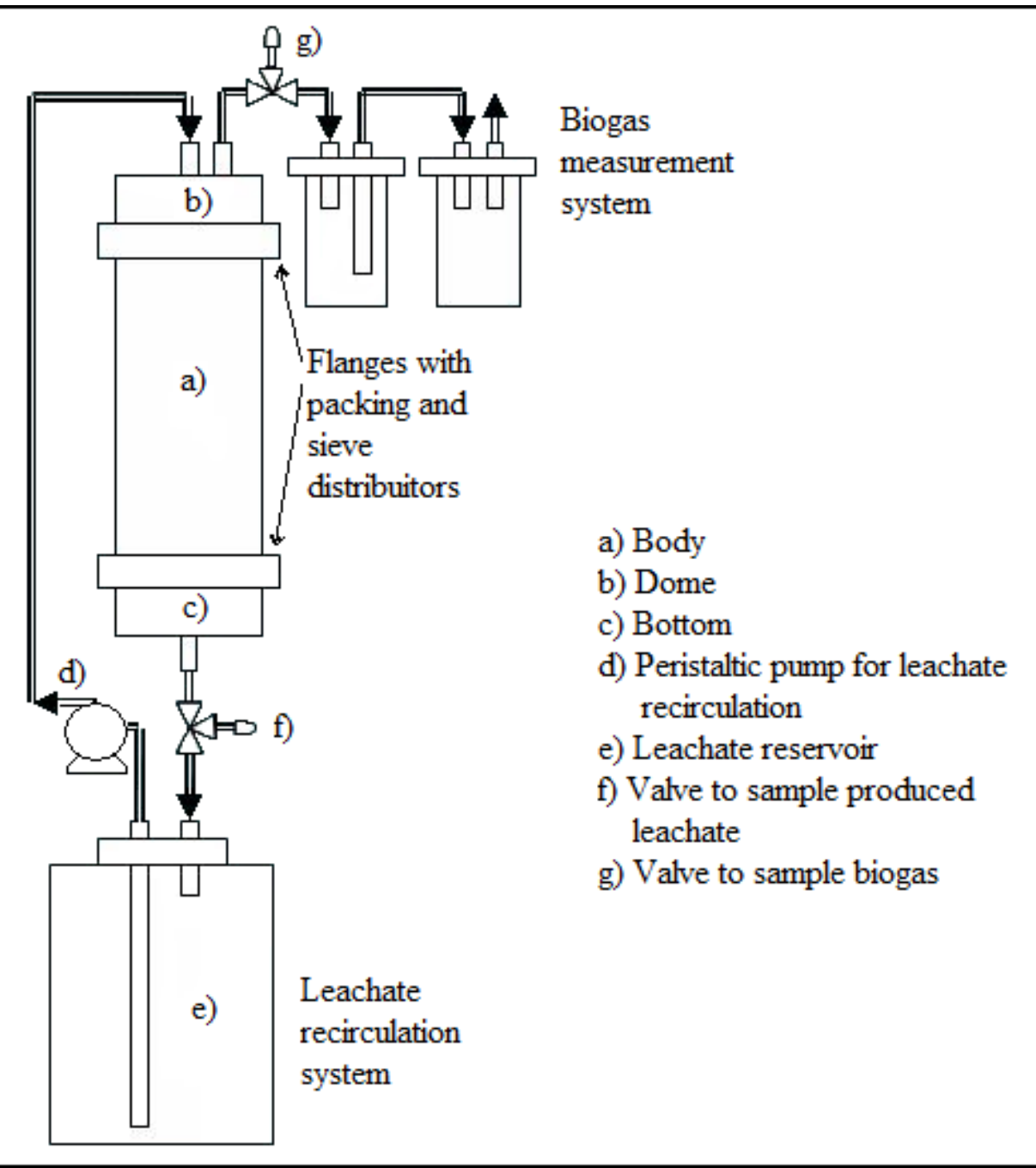

Fig. (1). Laboratory-scale biodigestor (LSB) fitted to biogas measurement and leachate recycling systems.

Table 2. Experimental Design at 4 Levels of $\% \mathrm{MC}$ by Leachate Recirculation

\begin{tabular}{|c|c|c|}
\hline $\begin{array}{c}\text { Moisture Content } \\
\text { Regimen (\%MC) }\end{array}$ & $\begin{array}{c}\text { Volume of Recirculation } \\
\text { Leachate Twice/Week (ml) }\end{array}$ & $\begin{array}{c}\text { Replicates } \\
\text { (LSBs) }\end{array}$ \\
\hline \hline Controls & 0 & 4 \\
\hline 50 & 62 & 4 \\
\hline 60 & 124 & 4 \\
\hline 70 & 248 & 4 \\
\hline 80 & 496 & 4 \\
\hline & & 20 \\
\hline
\end{tabular}

USEPA), and volatile fatty acids (VFA) using a gas chromatograph (VARIAN, CP 3800) fitted to a flame ionization detector (FID). The stainless steel column (length $2 \mathrm{~m}$, ID $2 \mathrm{~mm}$ ) was packed with 3\% CARBOWAX 20M + $0.5 \% \mathrm{H}_{3} \mathrm{PO}_{4}$, CROMOSORB WHP 20-200 MESH. The gas chromatograph was operated at a $25 \mathrm{ml} / \mathrm{min}$ constant flow and a threshold of 5.0. The injector and FID were maintained at a temperature of 210 and $220^{\circ} \mathrm{C}$, respectively. The oven temperature was programmed at $108{ }^{\circ} \mathrm{C}$ immediately after the injection of the sample and maintained for two minutes, afterwards, temperature was increased at a rate of $25{ }^{\circ} \mathrm{C} / \mathrm{min}$ until $120^{\circ} \mathrm{C}$ were reached and maintained for $0.2 \mathrm{~min}$, after which it was raised again at a rate of $8{ }^{\circ} \mathrm{C} / \mathrm{min}$ until reaching $145^{\circ} \mathrm{C}$. The VFA determined were acetic acid (AA), propionic acid (PA) and butyric acid (BA).

\subsubsection{Biogas Analyses}

Biogas was analyzed for methane $\left(\mathrm{CH}_{4}\right)$ in a gas chromatograph (VARIAN, CP 3800) using a FID. The stainless steel column (length $2 \mathrm{~m}$, ID $2 \mathrm{~mm}$ ) was packed with HAYESEP Q 80-100 MESH. Oxygen free nitrogen was used as carrier gas, at a constant flow rate of $30 \mathrm{~mL} / \mathrm{min}$. The temperature of the oven, injector and detector was maintained at 90,200 and $210^{\circ} \mathrm{C}$, respectively.

\subsubsection{Refuse Analyses}

All bioreactors were dismantled at the end of experimentation. Waste settlement was measured and solid waste was analyzed for $\mathrm{pH}$ and $\% \mathrm{MC}$ using Mexican Standard Norms [16]. TVS were determined by the $2540 \mathrm{G}$ method of APHA, AWWA and WEF [17]. 


\section{RESULTS}

\subsection{Solid Waste Mixture}

Table 3 presents the results of the analyzed parameters in the mixtures of MSW prepared with the 15 subproducts listed in Table 1, in the soil used as FC and in the mixture of both. As seen in Table 3, the addition of FC to the prepared MSW mixtures decreased $\mathrm{pH}, \% \mathrm{MC}$, TVS, $\mathrm{C}$ and $\mathrm{N}$ values. The soil used as FC contained $52.8 \%$ sand, $41.6 \%$ silt and $5.6 \%$ clay, corresponding to a sandy loam texture.

Table 3. Analyses of the Initial Mixture of Solid Waste

\begin{tabular}{|c|c|c|c|c|c|}
\hline \multirow{2}{*}{ Components } & \multicolumn{5}{|c|}{ Parameters } \\
\cline { 2 - 6 } & $\begin{array}{c}\text { Moisture } \\
\text { Content } \\
\text { (\%MC) }\end{array}$ & $\mathbf{p H}$ & TVS (\%) & $\mathbf{C ~ ( \% ) ~}$ & N (\%) \\
\hline \hline FC (soil) & $36.01 \pm 0.31$ & $5.43 \pm 0.03$ & $62.45 \pm 0.35$ & $1.42 \pm 0.28$ & $0.05 \pm 0.02$ \\
\hline MSW + FC & $39.70 \pm 0.42$ & $5.82 \pm 0.04$ & $64.70 \pm 0.47$ & $22.36 \pm 0.71$ & $1.18 \pm 0.14$ \\
\hline MSW & $40.25 \pm 0.55$ & $6.04 \pm 0.06$ & $76.95 \pm 0.56$ & $23.36 \pm 0.92$ & $1.53 \pm 0.17$ \\
\hline
\end{tabular}

\subsection{ANOVA and Tukey's Honestly Significant Differences Tests}

As each moisture content regime (50, 60, 70 and 80\% MC) was replicated in four LSBs, an ANOVA (95\% significance) was carried out among corresponding replicates for $\mathrm{pH}, \mathrm{CE}, \mathrm{TS}, \mathrm{SVT}, \mathrm{COD}, \mathrm{AA}, \mathrm{PA}, \mathrm{BA}$ and $\mathrm{CH}_{4}$. Since no statistically significant differences were found among means of the above-mentioned parameters in replicates of all $\% \mathrm{MC}$ regimes, it was possible to use the mean of each parameter's results for the four LSBs for a given $\% \mathrm{MC}$ regime.

However, ANOVA for 50, 60, 70 and 80\% MC regimes for each parameter analyzed showed that at least one of the means had significant differences. Tukey's HSD tests performed to find out among which \%MC regimes were such differences found. Data were divided for their analysis in three phases, as detailed in section 3.3.2 below: hydrolysis (day 1 to 12 ), acidogenesis (day 16 to 139 ) and methanogenesis (after day 139).
Table 4 contains the results of the Tukey's HSD tests for $\mathrm{pH}, \mathrm{EC}, \mathrm{TS}, \mathrm{TVS}, \mathrm{COD}, \mathrm{AA}, \mathrm{PA}, \mathrm{BA}$ and $\mathrm{CH}_{4}$, only presenting the treatment pairs showing statistically significant differences.

\subsection{Leachate Produced in LSB}

\subsubsection{Dynamics of Produced Leachate Volume}

Fig. (2) shows the volumes of leachate produced throughout the experiment by LSBs in the four $\% \mathrm{MC}$ regimes $(80,70,60$ and $50 \%)$. The field capacity was reached during the first day, even in the regime with the lowest volume of recirculated leachate [20]. No leachate was produced in any of the control LSBs.

\subsubsection{Dynamics of pH Value of Leachate from LSBS}

Fig. (3) shows the dynamics of leachate $\mathrm{pH}$ values. Leachate recycling, independently of the volume, allowed the establishment of the hydrolytic phase at the end of the first two weeks of operation. The acidogenic phase started at day 16 and ended during the period between day 97 and 139. The end of the acidogenic phase was considered to occur at $\mathrm{pH}$ values of 6.5 , as the system was able to support methane production.

\subsubsection{Dynamics of EC, TS, TVS and COD in Leachates from LSBs}

Figs. (4-7) show that, for all LSBs, the maximum values of EC, TS, TVS and COD were detected in the first leachates, possibly caused by the dissolution and drainage of inorganic and organic compounds by the initially added water $[21,22]$.

During hydrolysis and most of the acidogenic phase, leachate from LSBs operating at 50\% MC had higher values of EC, TS, TSS and COD, while these parameters were lowest in LSBs at 80\% MC (Figs. 5-8); which, most likely, was due to a dilution effect $[14,15]$.

According to Tukey's HDS multiple comparisons, during the hydrolysis phase, average EC values in leachates from LSBs at $80 \% \mathrm{MC}$ were significantly different from those in LSBs at 50 and $60 \% \mathrm{MC}$ (Table 4). According to the ANOVA test, EC of leachate had no significant differences among \%MC regimes in the acidogenic phase.

Table 4. Results of Tukey's HDS Tests at $95 \%$ Significance Level

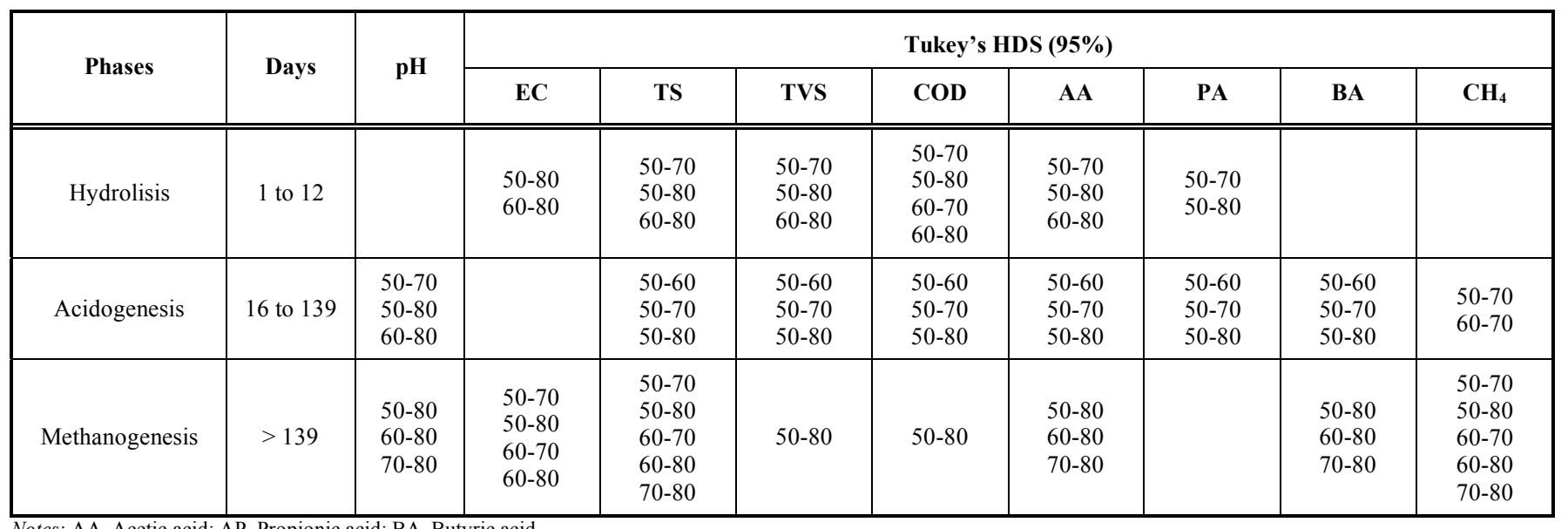




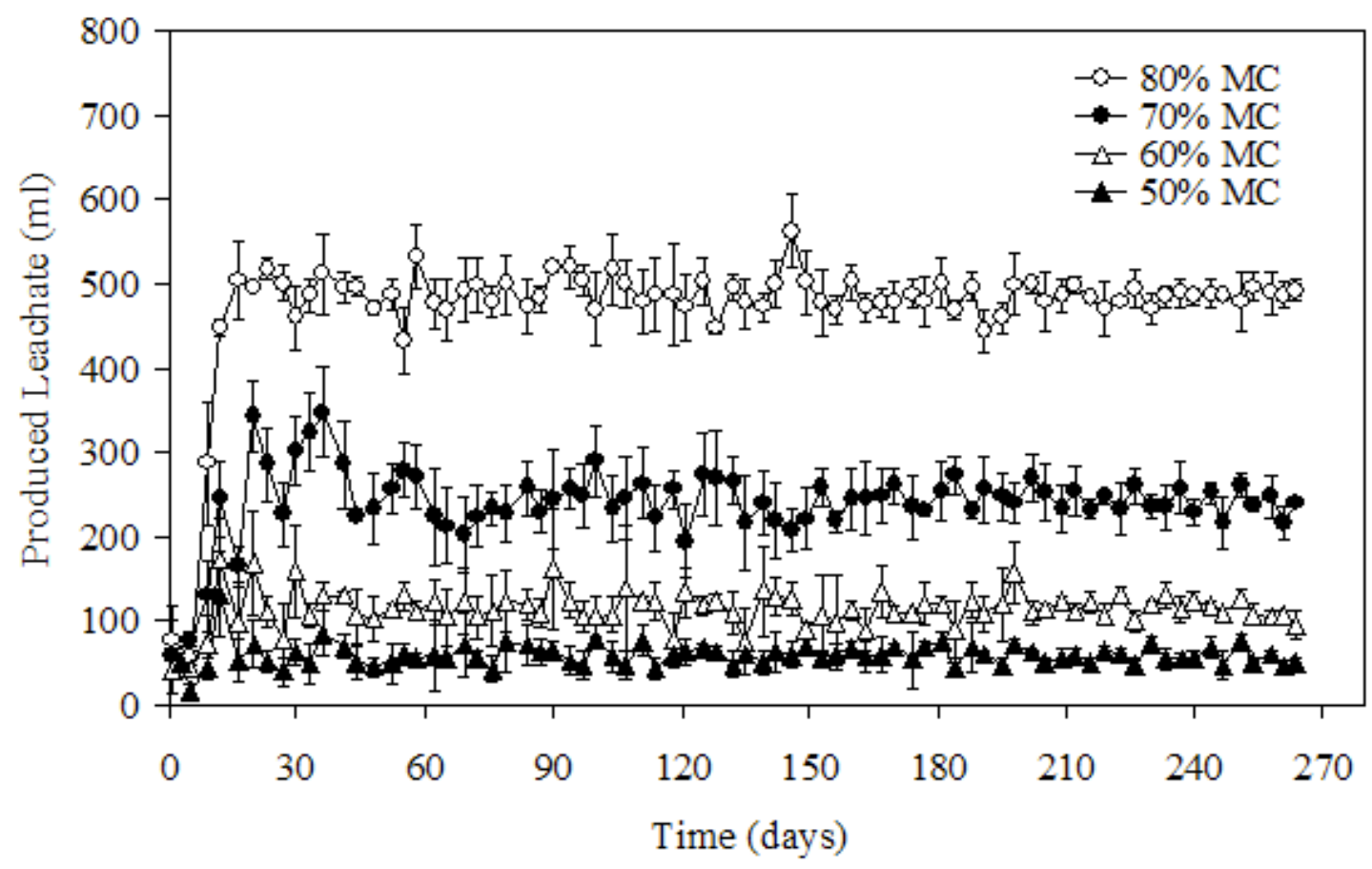

Fig. (2). Produced leachate volumes in recirculated LSBs at different moisture content (\%MC) regimes.

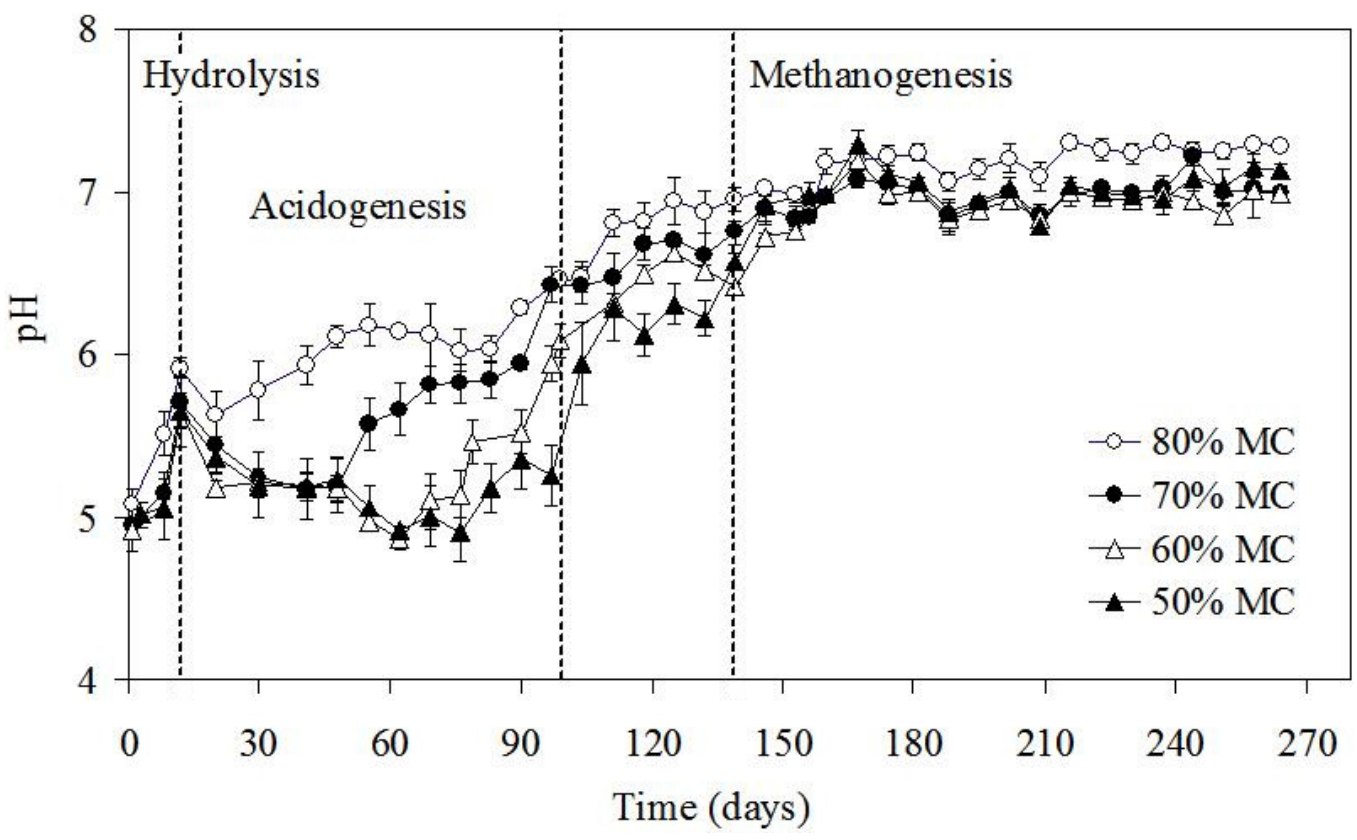

Fig. (3). Dynamics of $\mathrm{pH}$ value in leachates from LSBs at different moisture content (\%MC) regimes.

During the hydrolysis phase no statistically significant differences were found in TS, TVS and COD values between 50 and $60 \% \mathrm{MC}$ regimes (Table 4). In the acidogenic phase, the leachate produced at the $50 \% \mathrm{MC}$ regime also showed statistically significant differences in values of TS, TVS and $\mathrm{COD}$ with respect to the remaining $\mathrm{MC}$ regimes. Moreover, during the methanogenic phase statistically significant differences among $\mathrm{MC}$ treatments were observed for EC, TS, TVS and COD (Table 4), although such differences are not evident in Figs. (4-7).

In this work, the limit for stabilization was considered to be at $\mathrm{COD}$ values of $\leq 1000 \mathrm{mg} / \mathrm{L}$, therefore, the leachate from $80 \% \mathrm{MC}$ regime was the first to be stabilized at day 76 , whereas the leachate from the $50 \% \mathrm{MC}$ regime took the longest time to attain the same COD value at day 139 (Fig. 7). Furthermore, the time in which leachates from the 50 and $60 \% \mathrm{MC}$ regimes attained COD values $\leq 1000 \mathrm{mg} / \mathrm{L}$ also reached a $\mathrm{pH}$ value of 6.5 (Fig. 3).

\subsubsection{Dynamics of $A A, P A$ and $B A$ Production in Leachates from LSBS}

Figs. (8-10) show the average concentration of AA, PA and $\mathrm{BA}$ at different \%MC regimes, revealing that $[\mathrm{AA}]>$ $[\mathrm{BA}]>[\mathrm{PA}]$, in accordance to other authors [23]. 


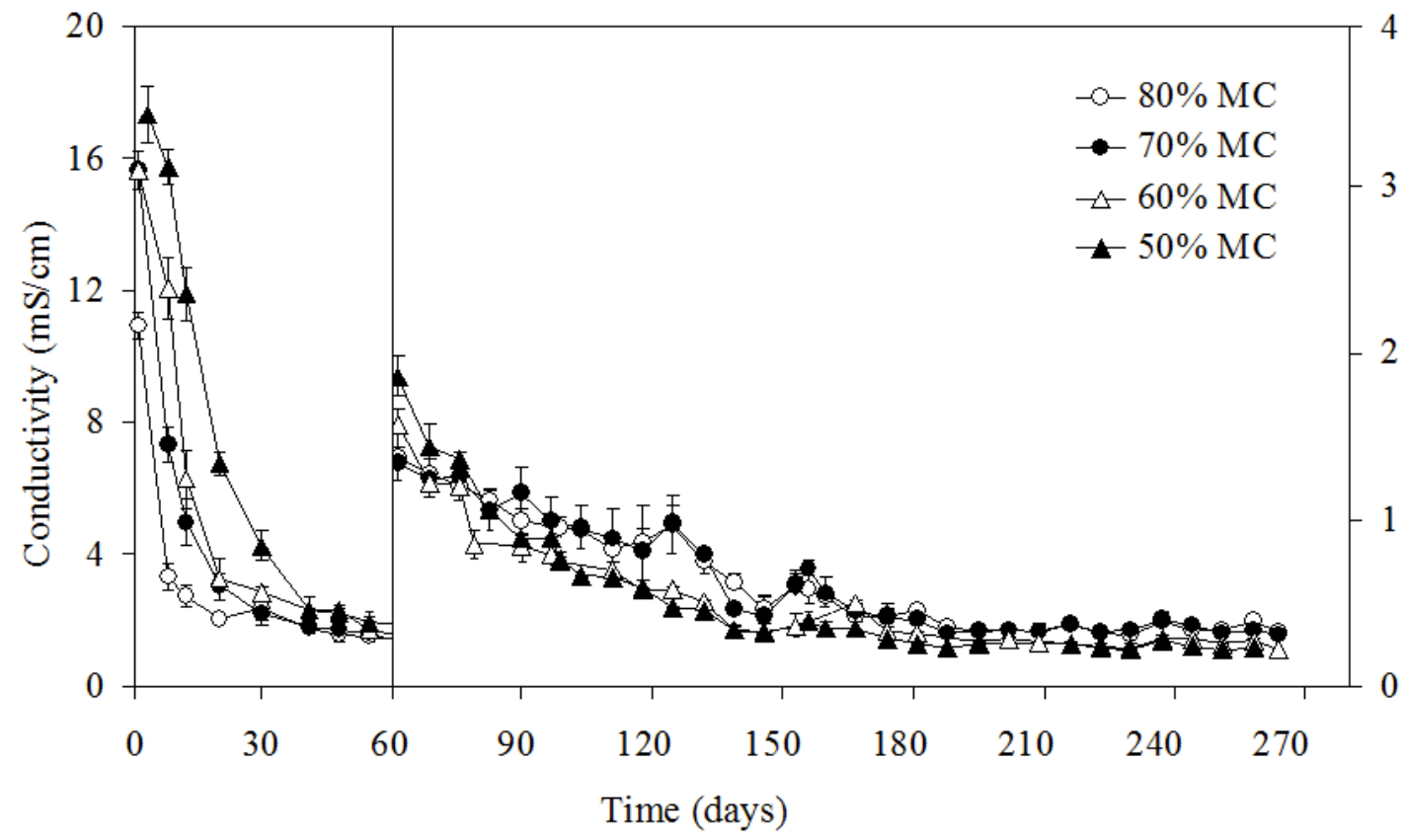

Fig. (4). Dynamics of electric conductivity in leachate from LSBs at different moisture content (\%MC) regimes.

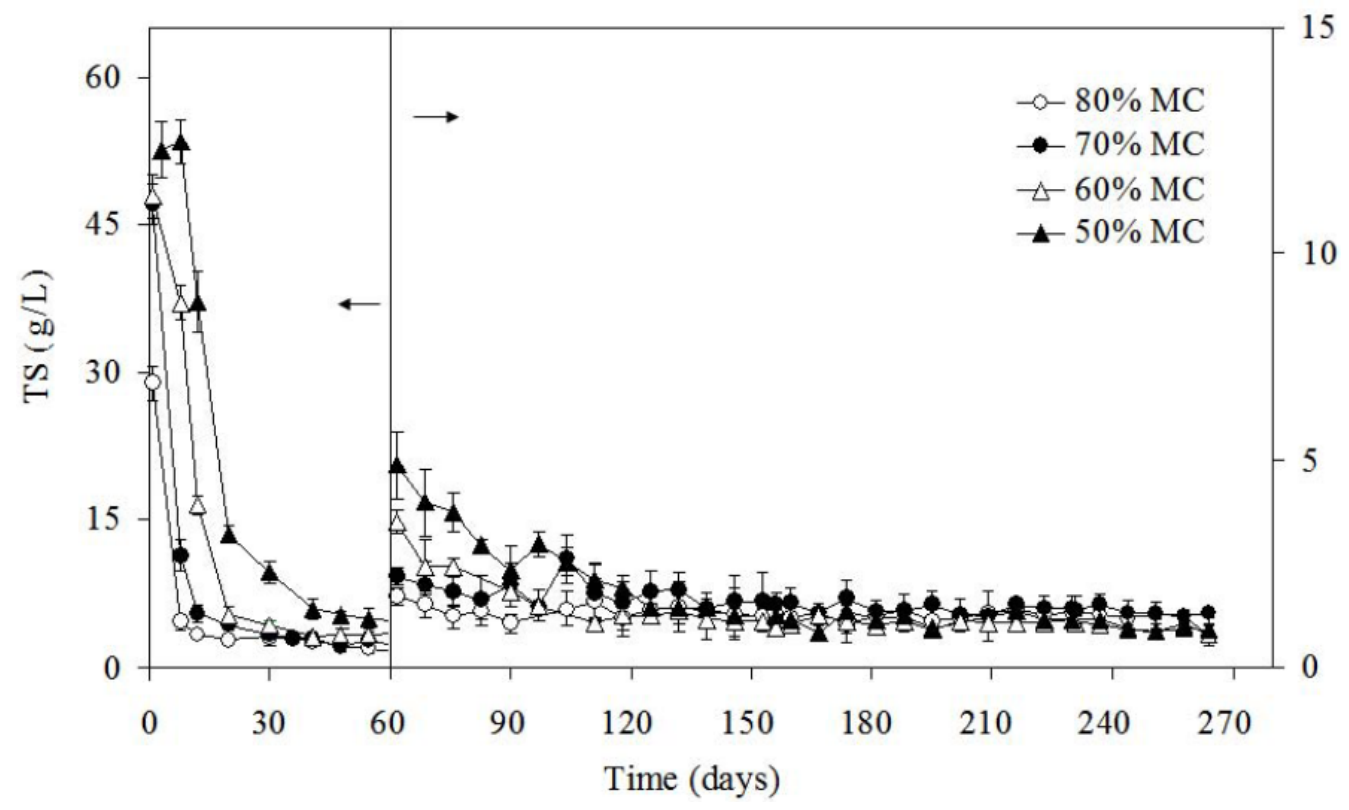

Fig. (5). Dynamics of TS values in leachates from LSBs at different moisture content (\%MC) regimes.

The highest concentrations of all VFA during the hydrolytic and acidogenic phases were recorded in LSBs at $50 \% \mathrm{MC}$, while the lowest were found in the $80 \% \mathrm{MC}$ LSBs, which produced the expected effect on $\mathrm{pH}$ and COD $[14,24]$.

According to Tukey's HDS test (Table 4), the concentrations of AA in the 50\% MC LSBs during the hydrolysis phase showed statistically significant differences to those values at 70 and $80 \%$, and between LSBs at $60 \%$ and those at $80 \% \mathrm{MC}$; while significant differences in the average concentration of PA were only observed between the LSBs at $50 \% \mathrm{MC}$ and between those at 70 and $80 \% \mathrm{MC}$. The concentrations of $\mathrm{AB}$ in leachate were not significantly affected by $\% \mathrm{MC}$ regimes.
During the acidogenic phase, statistically significant differences in concentrations of AA, PA and BA in leachates were only observed between LSBs at $50 \%$ and those at the remaining $\% \mathrm{MC}$ regimes. During the methanogenesis phase, statistically significant differences were found in AA and BA concentrations for $80 \% \mathrm{MC}$ LSBs with respect to all other $\% \mathrm{MC}$ regimes (Table 4 ).

Figs. $(\mathbf{8}, \mathbf{1 0})$ show that during the methanogenic phase the leachates with the highest concentrations of AA and BA were produced in the $80 \% \mathrm{MC}$ LSBs, although the observed concentrations ([AA] $<200 \mathrm{mg} / \mathrm{L} ;[\mathrm{BA}]<100 \mathrm{mg} / \mathrm{L}$ ) did not have an effect in the $\mathrm{pH}$ of the produced leachate (Fig. 4). 


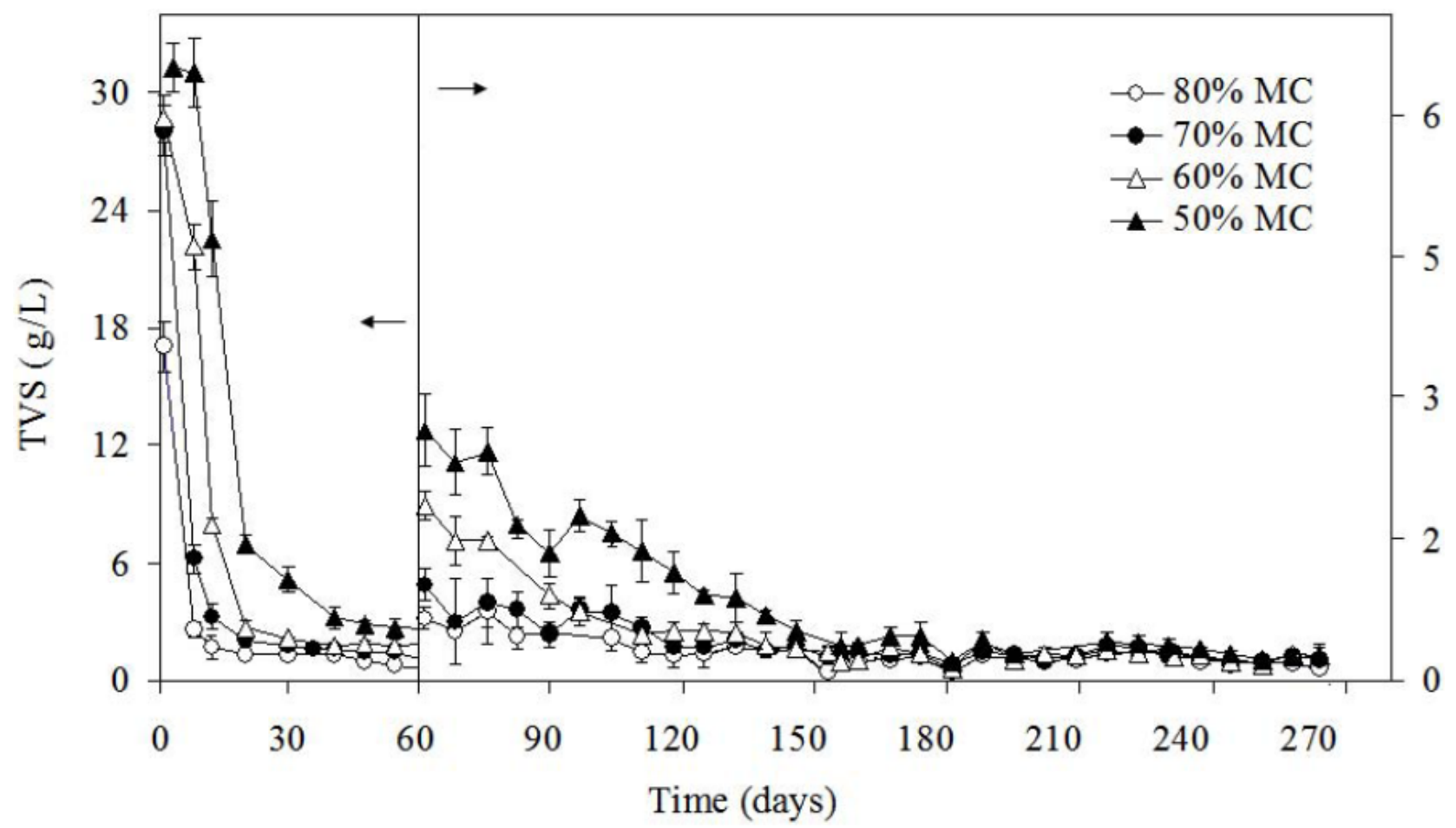

Fig. (6). Dynamics of TVS values in leachates from LSBs at different moisture content (\%MC) regimes.

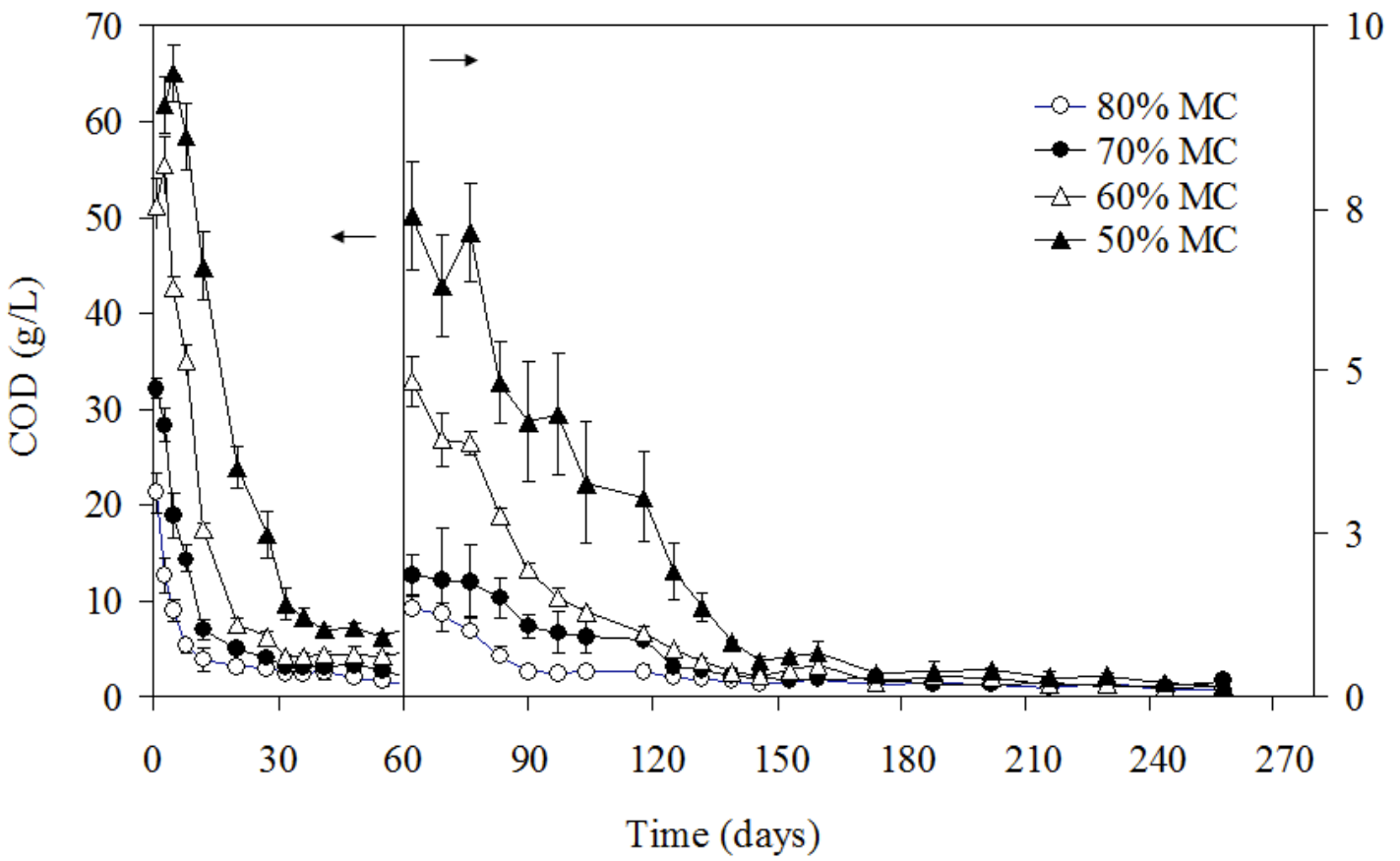

Fig. (7). Dynamics of COD values in leachates from LSBs at different moisture content (\%MC) regimes.

\subsection{Monitoring of Methane Generation}

Maximum methane in biogas was $41.4,54.7,51.3$ and $44.3(\%, \mathrm{~V} / \mathrm{V})$ for the $80,70,60$ and $50 \%$ bioreactors. Fig. (11) shows the cumulative average generation of $\mathrm{CH}_{4}$ from the decomposition of MSW loaded in LSBs at 50, 60, 70 and $80 \% \mathrm{MC}$ regimes. Methane was initially detected on day 48 in 70 and $80 \% \mathrm{MC} \mathrm{LSBs}$, and 14 days later (day 62) in the 50 and $60 \% \mathrm{MC}$ LSBs. Control LSBs showed no $\mathrm{CH}_{4}$ generation throughout the experimental period (264 days).
In general, the maximum rate of $\mathrm{CH}_{4}$ generation was reached by day 170 in each \% MC regime (Fig. 11). By the end of the experiment the LSBs at $80 \%$ MC produced 3.10 $\mu \mathrm{M} \mathrm{CH} / \mathrm{kg}$ dry MSW, while $4.81 \mu \mathrm{M} \mathrm{CH}_{4} / \mathrm{kg}$ dry MSW were generated at $70 \% \mathrm{MC}, 3.85 \mu \mathrm{M} \mathrm{CH}_{4} / \mathrm{kg}$ dry $\mathrm{MSW}$ at $60 \% \mathrm{MC}$ and $3.55 \mu \mathrm{M} \mathrm{CH} / \mathrm{kg}$ dry $\mathrm{MSW}$ at $50 \% \mathrm{MC}$. Tukey's HDS tests (Table 4) showed that, during the acidogenic phase, significant differences in $\mathrm{CH}_{4}$ generation were observed among LSBs at $70 \% \mathrm{MC}$ and those of the 50 


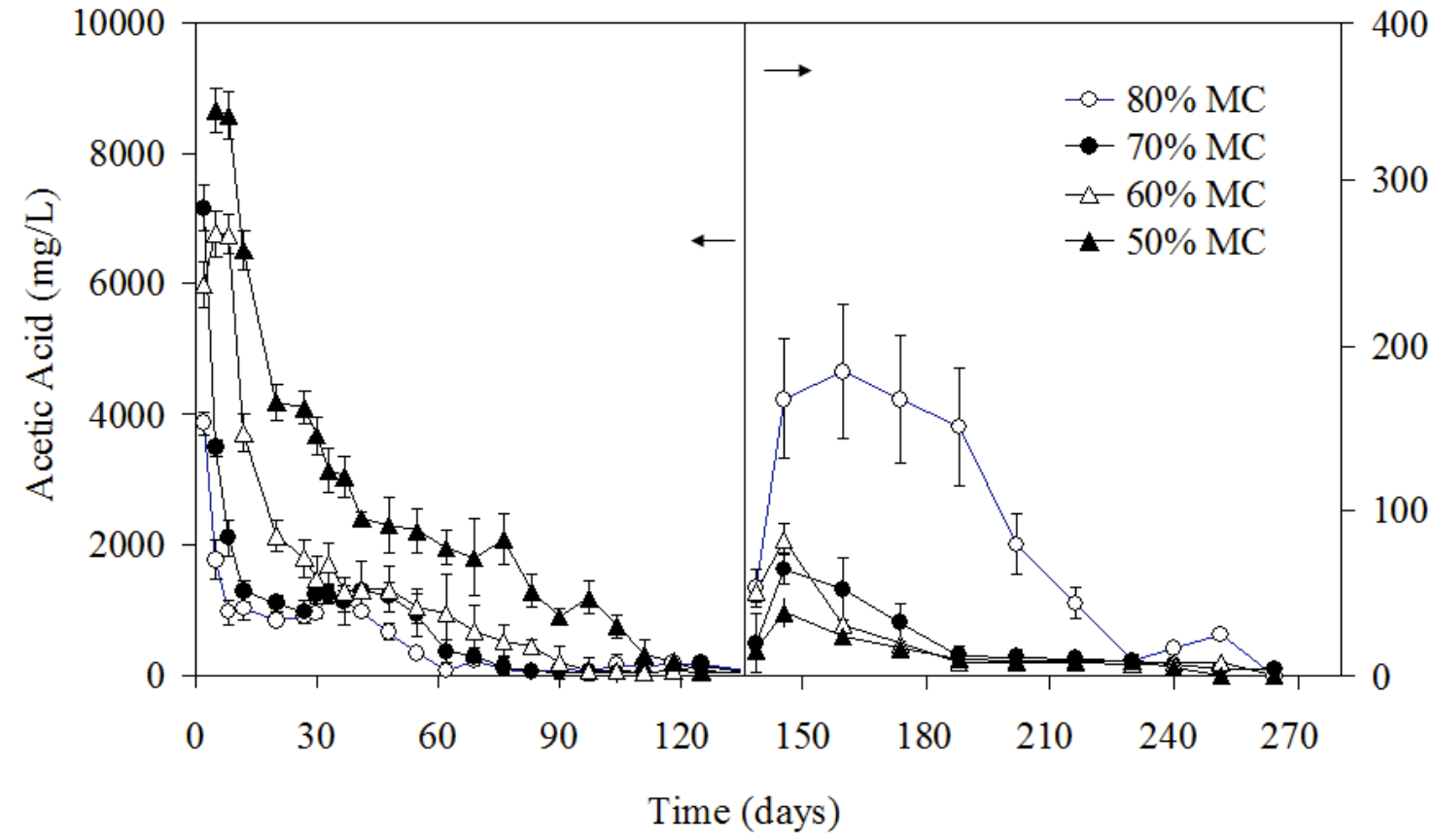

Fig. (8). Dynamics of acetic acid production in leachates from LSBs at different moisture content (\%MC) regimes.

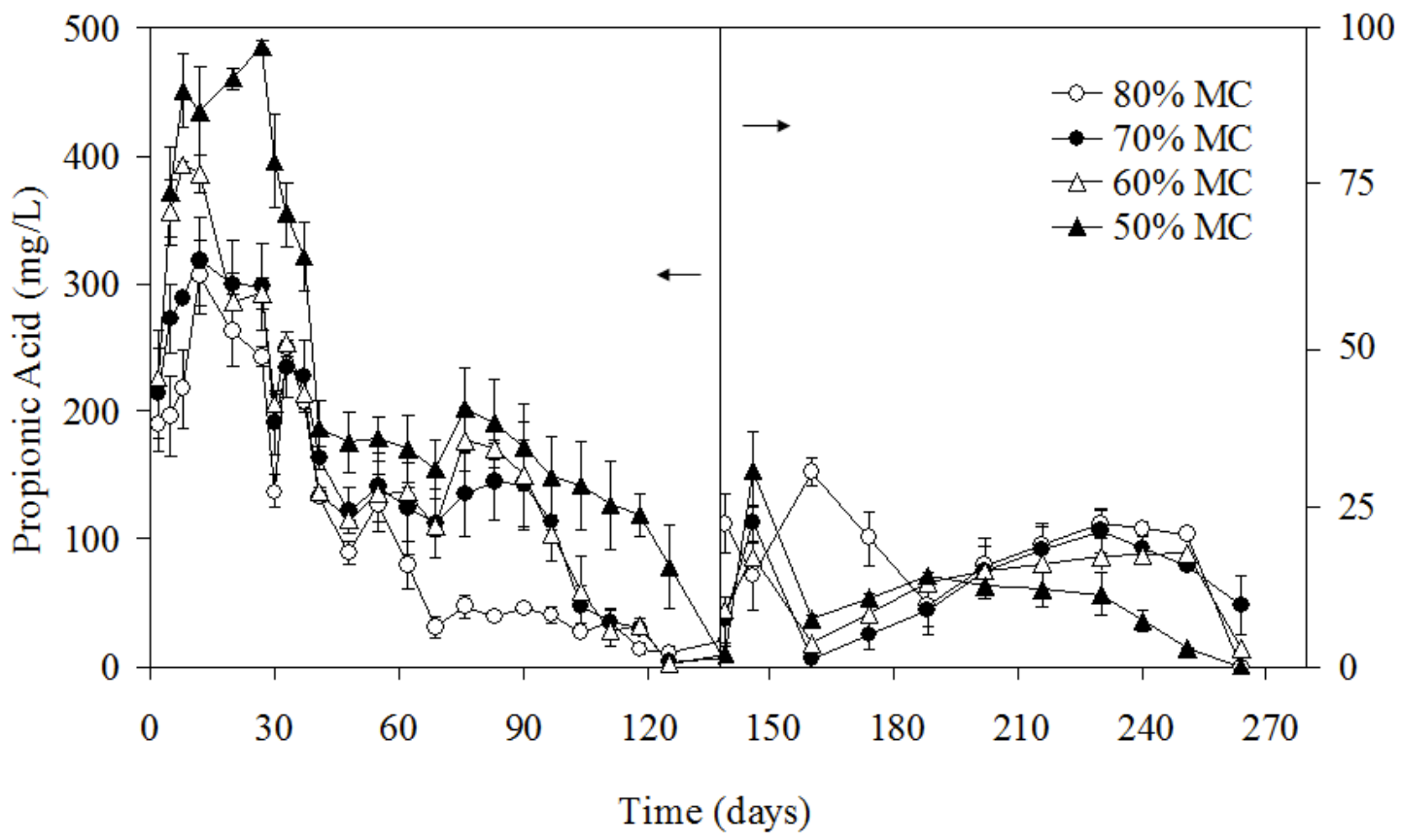

Fig. (9). Dynamics of propionic acid production in leachate from LSBs at different moisture content (\%MC) regimes.

and $60 \%$ MC. During the methanogenic phase, statistically significant differences were detected between LSBs at $70 \%$ $\mathrm{MC}$ and all other humidity ranges, and between $80 \% \mathrm{MC}$ and 50 and $60 \% \mathrm{MC}$; however, it is interesting to point out that the 50 and $60 \% \mathrm{MC}$ had similar methane production rates.

\subsection{Discharged Solid Wastes}

Table 5 contains the results of analyses at the end of the experiment of all studied parameters regarding $\mathrm{MSW}+\mathrm{FC}$ loaded in the LSBs and the digested MSW discharged from LSBs. Moisture contents correspond to the average field capacity of digested MSW for each LSBs regimen, as they were discharged 4 days after the last recirculation of their leachates. It was noticeable that $80 \%$ MC bioreactors presented the smallest moisture content than the remaining recycling regimes.

All the $\mathrm{pH}$ values of the digested MSW mixtures discharged from the LSBs approached neutrality and resembled the $\mathrm{pH}$ of the last drained leachates (Fig. 3), which is typical of mature residues [23-25].

Results indicate that the percent of settlement was proportional to $\% \mathrm{MC}$. In addition, the removal of TVS (\%) was greater at $70 \% \mathrm{MC}$, even when compared to the regime in which more volume was added (80\% MC). 


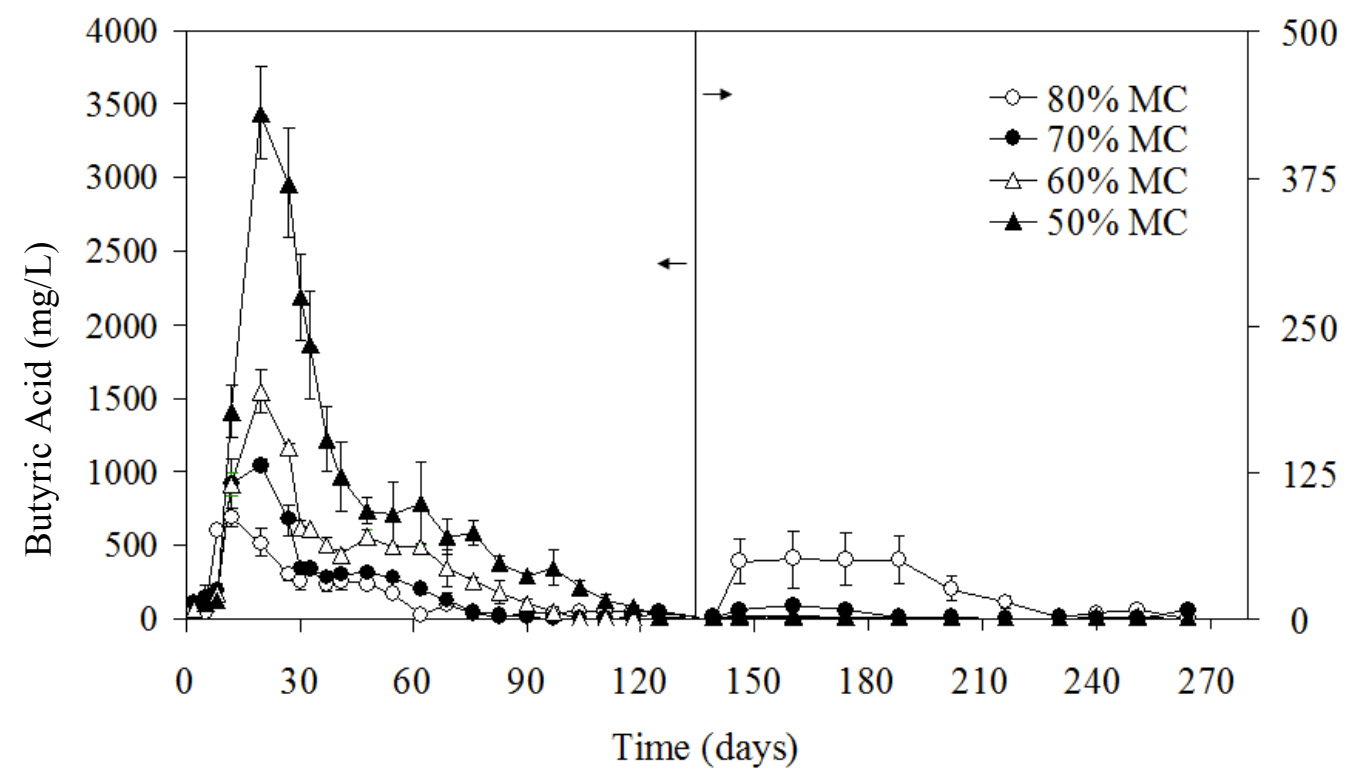

Fig. (10). Dynamics of butyric acid production in leachates from LSBs at different moisture content (\%MC) regimes.

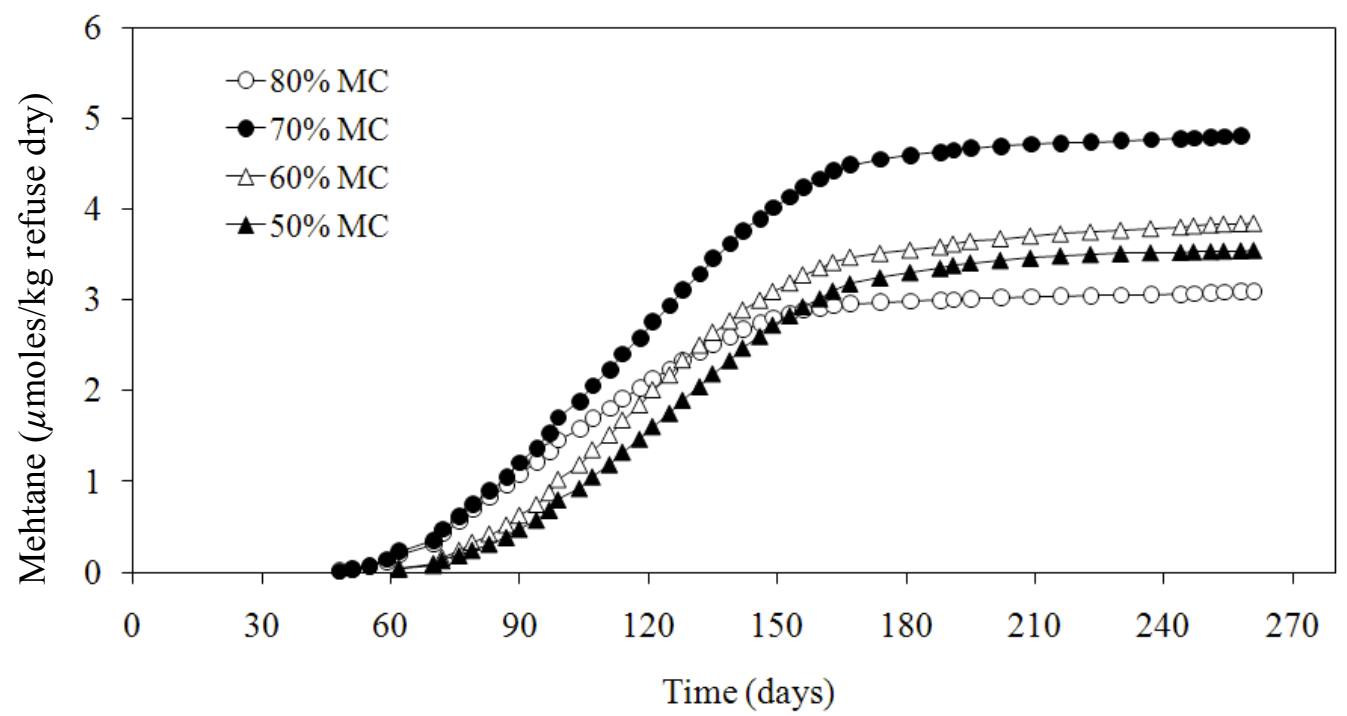

Fig. (11). Dynamics of accumulated methane in biogas from LSBs at differentmoisture content (\%MC) regimes.

Table 5. Results of Analyses of Solid Waste and Final Cover in LSBs Made at the Beginning and End of the Experiment

\begin{tabular}{|c|c|c|c|c|c|c|}
\hline MSW + FC & Leachating Time (Hours) & Moisture Content (\%) & pH & TVS (\%) & Removal of TVS (\%) & Settlement (\%) \\
\hline \hline Initial solid waste & - & $39.70 \pm 0.42$ & $5.82 \pm 0.04$ & $64.70 \pm 0.47$ & - & - \\
\hline $80 \% \mathrm{MC}$ & $1.13 \pm 0.12$ & $62.90 \pm 0.49$ & $7.18 \pm 0.03$ & $53.24 \pm 0.48$ & 17.71 & $11.54 \pm 1.34$ \\
\hline $70 \% \mathrm{MC}$ & $1.87 \pm 0.17$ & $64.70 \pm 0.43$ & $7.11 \pm 0.05$ & $50.23 \pm 0.47$ & 22.36 & $7.78 \pm 1.20$ \\
\hline $60 \% \mathrm{MC}$ & $2.30 \pm 0.22$ & $64.96 \pm 0.47$ & $7.65 \pm 0.05$ & $52.18 \pm 0.47$ & 19.35 & $5.04 \pm 0.93$ \\
\hline $50 \% \mathrm{MC}$ & $20.45 \pm 0.33$ & $63.99 \pm 0.46$ & $7.72 \pm 0.06$ & $52.56 \pm 0.45$ & 18.76 & $4.28 \pm 0.86$ \\
\hline Controls & - & $38.16 \pm 0.39$ & $6.74 \pm 0.03$ & $61.98 \pm 0.42$ & 4.20 & 0.00 \\
\hline
\end{tabular}

\section{DISCUSSION}

\subsection{Municipal Solid Waste}

The MSW loaded in the LSBs had an initial moisture content of $40.25 \%$, which falls within the $40-50 \% \mathrm{MC}$ value reported as typical of landfilled solid wastes [26]. The original acidity $(\mathrm{pH}=6.04)$ of MSW collected from the Pátzcuaro landfill suggests that these were partially decomposed. Addition of FC material made the $\mathrm{pH}$ value to descend to 5.82, which had an effect on the $\mathrm{pH}$ value of leachates produced during the first draining. 
The content of TVS in the initial mixture of MSW was high $(76.95 \%)$, both because it contained at least $79.56 \%$ of degradable matter (Table 1) and because the plastic content represented $11.98 \%(\mathrm{w} / \mathrm{w})$, which, as reported by Kelly et al. [27], has an effect in the content of TVS. The concentrations of $\mathrm{C}$ and $\mathrm{N}$ in the sample of MSW (Table 3) conditioned an initial $\mathrm{C} / \mathrm{N}$ ratio of 18.9 , which while being smaller than the optimal of 30 , did not imply a limitation to the decomposition process due to $\mathrm{N}$ concentration [28].

\subsection{Leachate Produced in LSBs}

\subsubsection{Dynamics of Produced Leachate Volume}

Table 5 shows that LSBs in the $80 \%$ MC regime were the first to reach field capacity, and therefore to produce leachate, followed by the 70,60 and $50 \% \mathrm{MC}$, nonetheless, they were also the last to produce equal leachate volume (Fig. 2), probably due to clogging as a result of excessive liquid in the interstice of the solid waste matrix. In fact, variations in produced leachate volumes are usually related to differences in leachate retention by solid waste, as added water or leachate when leaching, occupies the void spaces in the waste causing a bulk effect in bioreactors [29].

\subsubsection{Dynamics of pH Value of Leachate from LSBS}

The lower $\mathrm{pH}$ value measured in leachates produced by LSBs at 50 and $60 \% \mathrm{MC}$, with respect to the same at 70 and $80 \% \mathrm{MC}$, might be due to the accumulation of VFA in the solid waste matrix in the former LSBs [30], thus their acidogenic phase activity was extended. In other words, the volume of recirculated leachate in the 50 and $60 \% \mathrm{MC}$ regime LSBs was insufficient for the leaching of VFA, thus affecting the microenvironment in such a way that the onset of the methanogenic phase was delayed [31].

\subsubsection{Dynamics of EC, TS, TVS and COD in Leachate from LSBs}

During the hydrolysis, values of EC, TS, TVS and COD rapidly decreased, their fall being decelerated in the acidogenic phase mainly due to the formation of fatty acids [32-34]. Consequently, $\mathrm{pH}$ values decrease favoring the solubility of metals $[8,13]$. In addition, inorganic parameters such as chloride and amoniacal nitrogen tend to remain relatively constant and slowly diminish, even when subjected to leachate recycling $[13,15]$.

Even though $\mathrm{pH}$ values in the 50 and $60 \% \mathrm{MC}$ were more acidic than those in the 70 and $80 \%$ MC (Fig. 3), EC values were similar (Table 4), which has a two-fold explanation: acidic $\mathrm{pH}$ values are known to propitiate ion dilution $[8,35]$; but in the other case, the EC is likely to be related to drainage of compounds by the higher volumes of recycled leachate in the 70 and $80 \% \mathrm{MC}$ [15].

In the hydrolysis phase no statistically significant differences were found in TS, TVS and COD values between 50 and $60 \% \mathrm{MC}$ regimes (Table 4), suggesting that the dilution of organic and inorganic compounds was similar [14]. Moreover, in the 70 and $80 \% \mathrm{MC}$, these parameters did not reveal any significant effect in the leachate produced, in spite of volume being twice as large.

Even though some authors have reported COD values $\leq$ $2000 \mathrm{mg} / \mathrm{L}$ as the limit for stabilization [24], in this experiment that value was reached in a date in which none of the LSBs had reached the methanogenic phase. Hence, we set the stabilization limit as $\leq 1000 \mathrm{mg} / \mathrm{L}$ of COD. In addition, this set point meant that leachate stabilization occurred earlier at higher volumes of recirculation. This inverse proportionality can be attributed to a better nutrient distribution $[13,36]$; however, this is not necessarily related to a higher methane production, as the $80 \% \mathrm{MC}$ did not present the highest methane production rate. These results suggest that the most appropriate leachate recycling regime was $70 \% \mathrm{MC}$, and also, that leachate of high organic loads can be reduced and stabilized in short time periods, which makes BSLs to be a viable biotechnological alternative for leachate treatment $[4,9,12,37]$.

\subsubsection{Dynamics of the Concentrations of Short-Chain Organic Acids (AA, PA and $B A$ ) in Leachates from LSBS}

PA and BA concentration (Figs. 9, 10) increased in the first days due to accumulation of hydrolytic products and started to decrease afterwards due to conversion into biogas [38]. During acidogenic phase, LSBs in the 50\% MC showed the highest VFA concentrations, and therefore the highest $\mathrm{COD}$ values and lowest $\mathrm{pH}$ values. In addition, the $50 \% \mathrm{MC}$ was the only moisture regimen that was statistically different to the rest. This situation might be explained either by a more vigorous VFA generation or by a lesser acid consumption as substrate. However, the latter might be more plausible, as small recycling volumes also account for poor nutrient distribution [23, 24, 32].

On the other side, $80 \% \mathrm{MC}$ reactors showed the highest $\mathrm{AA}$ and $\mathrm{BA}$ concentrations throughout the methanogenic phase, suggesting that the recycled volume did not allow adequate contact between nutrients and methanogenic bacteria, which is further evidenced by the fact that this regime produced the lowest methane production rate (Fig. 11). Even though most authors coincide in stating that higher recycling volumes correspond to higher degradation rates, our findings and those from other authors such as Sponza and Ada [15], strongly suggest that there is a limit to that practice when high VFA concentrations and low methane production rates are evidences of wash out.

\subsection{Monitoring of Methane Generation}

The onset of the methanogenic phase in the 50,60 and $70 \%$ MC LSBs (Fig. 11) was correlated to the $\mathrm{pH}$ recovery (Fig. 3), as the conversion of $\mathrm{AA}$ and $\mathrm{H}_{2}$ to $\mathrm{CH}_{4}$ and $\mathrm{CO}_{2}$ takes place [23, 38, 39]. Furthermore, comparing the cumulative $\mathrm{CH}_{4}$ of those LSBs, it is evident that higher recycled leachate is equivalent to a better nutrient distribution and hence to a higher microbial activity $[14,36]$. Nonetheless, as stated before, the recycled volume at $80 \%$ MC was excessive, causing nutrient wash out and a consequent reduction in biodegradation $[15,21,34]$. Additionally, some inhibitory compounds could have accumulated, such as ammoniacal nitrogen [34] or heavy metals $[13,40]$, which should be considered in subsequent works.

\subsection{Discharged Solid Wastes}

It is likely that in the $80 \%$ MC channeling formation occurred, explaining the smallest moisture content and the 
highest settlement grade (Table 5), coincidental to a wash out in the system $[14,15,21]$.

The MSW matrix settlement \% was higher in the $80 \%$ MC regime, such a settlement level could have been due to the diminishment of present voids in the material and not exclusively to decomposition of the organic matter present in the MSW, as suggested by the higher losses of TVS in LSBs at $70 \%$ MC $[29,41]$. Moreover, as stated before, settlement degrees were directly proportional to volume of recycled leachate, in accordance to results from other works [13, 37]. At full scale this is very important because rapid and predictable settlement can provide an opportunity to utilize space prior to cell or landfill site closure [13, 25].

It is important to point out that the largest TVS removal was obtained in the LSBs at $70 \% \mathrm{MC}$, indicating a higher degree of degradation of the organic matter [21, 25, 27], consistently with a higher methane generation rate (Fig. 11).

\section{CONCLUSIONS}

In this research, the performance of bioreactors under leachate recycling regimes of $50,60,70$ and $80 \% \mathrm{MC}$ was studied. Using $\mathrm{pH}$ value of produced leachate as an indicator, it was possible to clearly identify hydrolysis, acidogenic and methanogenic phases of the refuse biodegradation process. Among these phases, the acidogenic period was longer when facing smaller volumes of leachate, while during the hydrolysis phase the application of different recycling volumes did not produce a significant variation of $\mathrm{pH}$. The utilization of different leachate volume recycling did influence the MSW anaerobic degradation and this was reflected differently in individual phases. During the hydrolysis phase, due to a dilution effect and a perfusion process in the waste matrix, the volume of water or recycled leachate proportionally influenced leachate characteristics. In the acidogenic phase, recycled volumes were also responsible for variations in the leachate composition, but the $50 \% \mathrm{MC}$ was the only one producing significant differences and higher concentrations of the analyzed parameters. Furthermore, our results prove that starting at the volume in the $60 \% \mathrm{MC}$, the duplicating or even quadruplicating the recycled volume does not produce significant differences in leachate characteristics. A stabilization limit of COD $\leq 1000 \mathrm{mg} / \mathrm{L}$ was set, evidencing that the required time for stabilization is inversely proportional to the recycled volume. Nonetheless, our results point out that in the $80 \% \mathrm{MC}$, the attained stabilization resulted of a dilution effect on the recycled leachate, instead of being the effect of an accelerated biodegradation of the organic matter.

The obtained results demonstrate that, among the studied moisture regimes, the $70 \% \mathrm{MC}$ was the most appropriate in terms of MSW anaerobic biodegradation. Nevertheless, this research was conducted at a laboratory scale and results should be cautiously considered. Regardless of the scale, generated information clearly point out that leachate volume in the $80 \% \mathrm{MC}$ bioreactors was excessive, rendering it unsuitable to operate under similar moisture conditions. The importance of this is paramount, as there is a wide availability of reports that state the multiple advantages of leachate recycling to enhance MSW degradation, but only a handful have studied how leachate recycling may exert an undesirable effect on methane production.

Finally, it is clear that leachate recycling in MSW is a biotechnological alternative for an in situ treatment, as it can decrease leachate concentrations and produce stabilization in shorter periods, however, this requires a cautious approach. Low concentrations in leachate might be due only to high recycled leachate volumes, making it necessary to take in account other information such as methane generation rates and, if possible, also information derived from the solid matrix itself. Moreover, it is also expected that the solid waste matrix is impacted by leachate recycling due to the occurrence of physical changes such as settlement or channeling, and more important, there is a limit to the highest TVS removal proportion that may not necessarily correspond to the highest recycled volume of leachate. Further research should be carried out to study the effect of leachate concentration and to monitor the characterization of the leachate when added to the refuse column, not only after it has leached through the column.

\section{ACKNOWLEDGEMENTS}

The excellent technical support of Ms Elizabeth Martínez, Mr Carlos G. Prado and Mr Erick A. Mendoza is gratefully acknowledged.

\section{REFERENCES}

[1] SEMARNAT (Secretaria de Medio Ambiente y Recursos Naturales) Environmental and Natural Resources Secretary, La gestión ambiental en México (Environmental management in Mexico). ISBN 968-817-799- 7, (in Spanish). México, D. F. 2006.

[2] D. P. Komilis, R. K. Ham, and R. Stegmann, "The effect of landfill design and operation practices on waste degradation behavior: a review", Waste Manage. Res., vol. 17, pp. 20-26, January 1999.

[3] P. H. L. Nguyen, P. Kuruparan, and C. Visvanatha, "Anaerobic digestion of municipal solid waste as a treatment prior to landfill", Bioresour. Technol., vol. 98, pp. 380-387, January 2007.

[4] D. R. Reinhart, P. T. McCreanor, and T. G. Townsend, "The bioreactor landfill: Its status and future", Waste Manage. Res., vol. 20, pp. 172-186, January 2002.

[5] B. Shearer, "Enhanced Biodegradation in Landfills", M. S. thesis, The Faculty of Virginia Polytechnic Institute and State University. USA. 2001.

[6] LGPGIR (Ley General para la Prevención y Gestión Integral de los Residuos), General Law for Waste Prevention and Management. DOF (Diario Oficial de la Federación) Federal Official Newspaper, (in Spanish). México, D. F. October 8, 2003.

[7] E. D. Yildiz, K. Ünlü, and R. K. Rowe, "Modeling leachate quality and quantity in municipal solid waste landfills". Waste Manage. Res., vol. 22, pp. 78-92, January 2004.

[8] P. Kjeldsen, M. A. Barlaz, A. P. Rooker, A. Baun, A. Ledin, and T. H. Christensen, "Present and long-term composition of MSW landfill leachate: a review", Crit. Rev. Environ. Sci. Technol., vol. 32, pp. 297-336, March 2002.

[9] J. Pacey, D. Augenstein, R. Morck, D. Reinhart, and R. Yazdani, "The bioreactor landfill - an innovation in solid waste management", Solid Waste Association of North America (SWANA). USA 2000.

[10] Foth and Van Dike. Landfill Leachate Recirculation and Landfills with Methane Recovery. Foth \& Van Dike and Associaties, Inc. Eagan, Minnesota, USA. September 2004.

[11] M. A. Barlaz, R. K. Ham, D. M. Schaefer, and R. Isaacson, "Methane production of municipal refuse: a review of enhancement techniques and microbial dynamics", Crit. Rev. Environ. Sci. Technol., vol. 19, pp. 557-584. January 1990.

[12] F. G. Pohland, and J. C. Kim, "In situ anaerobic treatment of leachate in landfill bioreactors", Water Sci. Technol., vol. 4, pp. 203-210, January 1999.

[13] D. R. Reinhart, and A. B. Al-Yousfi, "The impact of leachate recirculation on municipal solid waste landfill operating 
characteristics", Waste Manage. Res., vol.14, pp. 337-346. January 1996.

[14] S. Chugh, W. Clarke, P. Pullammanappallil, and V. Rudolph, "Effect of recirculated leachate volume on MSW degradation", Waste Manage. Res., vol. 16, pp. 564-573. January 1998.

[15] D. T. Sponza, and O. N. Ada, "Impact of leachate recirculation and recirculation volume on stabilization of municipal solid wastes in simulated anaerobic bioreactors", Process Biochem., vol. 39, pp. 2157-2165, October 2004.

[16] SEMARNAT (Secretaria de Medio Ambiente y Recursos Naturales) Environmental and Natural Resources Secretary, Normas mexicanas vigentes (Mexican Official Norms). [Online]. Available at: http://www.semarnat.gob.mx/leyesynormas/Pages/nor masmexicanasvigentes.aspx (in Spanish) [Accessed 15.08.08] 2008.

[17] APHA, AWWA and WEF, Standard Methods for the Examination of Wastewater. $20^{\text {th }}$ ed., American Public Health AssociationAmerican Water Works Association, Water Environment Federation Publication, Washington, DC., USA. 1998.

[18] G. J. Bouyoucos, "Hydrometer method improved for making particle size analyses of soils", Agron. J., vol. 54, pp. 464-465, January 1962.

[19] Hach, USEPA-Approved Dichromate COD Method. Lit. No. 4257, H74 CHach Company. Printed in USA, 1997.

[20] M. T. Orta de Velázquez, R. Cruz-Rivera, N. Rojas-Valencia, I. Monje-Ramírez, and J. Sánchez-Gómez, "Determination of field capacity of municipal solid waste with surcharge simulation", Waste Manage. Res., vol. 21, pp. 137-144, January 2003.

[21] Ma. C. Hernández-Berriel, L. Márquez-Benavides, D. J. GonzálezPérez, and O. Buenrostro-Delgado, "The effect of moisture regimes on anaerobic degradation of municipal solid waste from Metepec (Mexico)", Waste Manage., vol. 28, pp. S14-S20, June 2008.

[22] R. Munasinghe, "Effect hydraulic retention time on landfill leachate and gas characteristics", PhD Thesis. The Faculty of Graduates Studies Civil Engineering in the University of British Columbia. Canada, 2003.

[23] M. A. Barlaz, D. M. Schaefer, and R.K. Ham, "Bacterial population development and chemical characteristics of refuse decomposition in a simulated sanitary landfill", Appl. Environ. Microbiol., vol. 55, pp. 55-65, January 1989.

[24] V. Francois, G. Feuillade, G. Matejka, T. Lagier, and N. Skhiri, "Leachate recirculation effects on waste degradation: Study on columns", Waste Manage., vol. 27, pp. 1259-1272, December 2007.

[25] C. H. Benson, M. A. Barlaz, D. T. Lane, and J. M. Rawe, "Practice review of five bioreactor/recirculation landfills", Waste Manage., vol. 27, pp. 13-29, January 2007.

[26] P. Kjeldsen, and M. Christophersen, "Composition of Leachate from Old Landfills in Denmark", Seventh International Waste Management and Landfill Symposium. S. Margherita di Pula, Cagliari, Italy; CISA, Environmental Sanitary Engineering Centre, Cagliari, Italy, 1999.

[27] R. J. Kelly, B. D. Shearer, J. Kim, C. D. Goldsmith, G. R. Hater, and J. T. Novak, "Relationships between analytical methods utilized as tools in the evaluation of landfill waste stability", Waste Manage., vol. 26, pp. 1349-1356, October 2006.

[28] M. Kayhanian, "Biodegradability of the organic fraction of municipal solid waste in a high-solids anaerobic digester", Waste Manage. Res., vol. 13, pp. 123-136, January 1995.

[29] S. Sri Shalini, O. P. Karthikeyana, and K. Joseph, "Biological stability of municipal solid waste from simulated landfills under tropical environment" Bioresour. Technol., vol. 101, pp. 845-852, January 2010.

[30] L. Márquez-Benavides, and I. Watson-Craik,. "Effect of intermediate soil cover on municipal solid waste decomposition", Water Sci. Technol., vol. 48, pp. 245-248, January 2003.

[31] N. Sanphoti, S. Towprayoon, P. Chaiprasert and A. Nopharatana, "The effects of leachate recirculation with supplemental water addition on methane production and waste decomposition in a simulated tropical landfill", J. Environ. Manage., vol. 81, pp. 2735, March 2006.

[32] M. A. Barlaz, "Microbiology of solid waste landfills," In Microbiology of Solid Waste. Palmisano, A.C. and Barlaz, M.A. Ed. CRC Press. Boca Raton, Florida, USA, 1996.

[33] L. Castrillón, Y. Fernández-Nava, M. Ulmanu, I. Anger, and E. Marañón, "Physico-chemical and biological treatment of MSW landfill leachate", Waste Manage., vol. 30, pp. 228-235, January 2010.

[34] G. T. Ellis, J. Park, E. Debik, and S. Smith, "Evaluation of Leachate Treatment and Recycle Options at the Boone County Landfill", in The Twenty International Conference on Solid Waste Technology and Management. Philadelphia, PA USA, 2005.

[35] M.S. Bilgili, A. Demir, and B. Ozkaya, "Influence of leachate recirculation on aerobic and anaerobic decomposition of solid wastes", J. Hazard. Mater., vol. 143, pp. 177-183, January 2007.

[36] R. Ravishankar, P. Ravichandra, and G. Mugeraya, "Effect of MSW leachate recirculation frequency on contaminants reduction", in The Twenty Two International Conference on Solid Waste Technology and Management. Philadelphia, PA USA, pp. 258-269, February 2007.

[37] M. Swati, J. Kurgan, and R. Nagendran, "Bioreactor landfill lysimeter studies on an Indian urban refuse", in Tenth International Waste Management and Landfill Symposium. CISA, Environmental Sanitary Engineering Centre, S. Margherita di Pula, Cagliari, Italy, 2005.

[38] R. Valencia, W. van der Zon, H. Woelders, H. J. Lubberding, H. J. Gijzen, "Achieving "Final Storage Quality" of municipal solid waste in pilot scale bioreactor landfills", Waste Manage., vol. 29, pp. 78-85, January 2009.

[39] N. Calace, A. Massimiani, B. M. Petronio, and M. Pietroletti, "Municipal landfill leachate-soil interactions: a kinetic approach", Chemosphere, vol. 44, pp. 1025-1031, December 2001.

[40] A. Watson, and D. B. Nedwell, "Methane production and emission from peat: the influence of anions (sulphate, nitrate) from acid rain", Atmos. Environ., vol. 32, pp. 3239-3245, December 1998.

[41] M. S. Hossain, M. A. Gabr, and M. A. Barlaz, "Relationship of compressibility parameters to municipal solid waste decomposition", J. Geotechn. Geoenviron. Eng., vol. 129, pp. 1151-1158, December 2003. 